\title{
BIOGRAFIA DR HAB. JERZEGO ZYGMUNTA DZIECIUCHOWICZA, PROF. UL
}

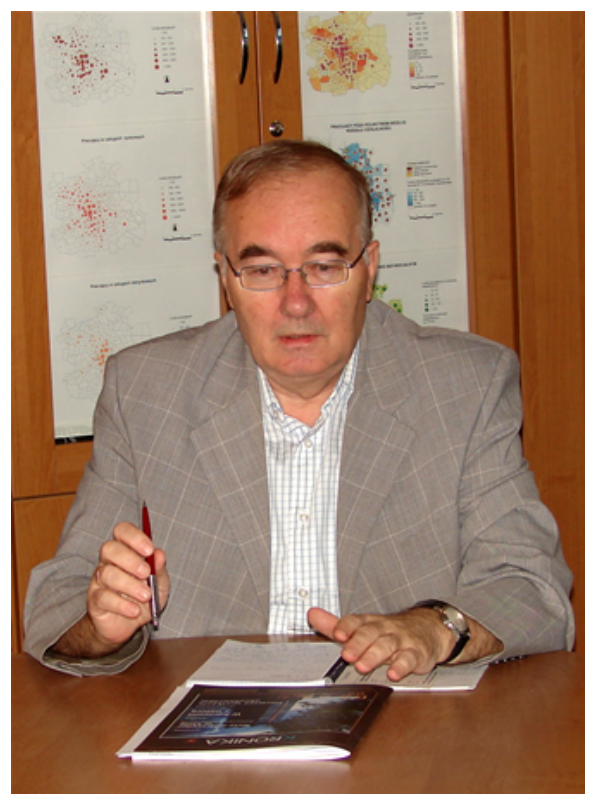

Profesor Jerzy Zygmunt Dzieciuchowicz urodził się 19 czerwca 1943 r. w Monachium (Niemcy). Jest synem Stanisława Dzieciuchowicza oraz Józefy z domu Stachowicz. Profesor wywodzi się $\mathrm{z}$ rodziny robotniczej. Dyplom dojrzałości uzyskał w 1961 r. po ukończeniu XXIII Liceum Ogólnokształcącego w Łodzi im. ks. prof. Józefa Tischnera (mieszczącego się przy al. Marsz. J. Piłsudskiego). Po ukończeniu szkoły średniej rozpoczął studia na kierunku geograficznym Wydziału Biologii i Nauk o Ziemi Uniwersytetu Łódzkiego. W 1966 r. przygotowal oraz obronił pracę magisterską pt. Osiedle mieszkaniowe Widzew-Zachód w Lodzi. Monografia geograficzno-ekonomiczna.

Promotorem tej pracy był prof. dr hab. Ludwik Straszewicz. Bezpośrednio po uzyskaniu dyplomu magistra ze specjalnością geografia ekonomiczna rozpoczął pracę naukowo-dydaktyczną w Katedrze Geografii Ekonomicznej UŁ na stanowisku asystenta-stażysty, a po roku na stanowisku asystenta. Od roku 1969 J. Dzieciuchowicz pracował na stanowisku starszego asystenta. Stopień doktora nauk geograficznych uzyskał na podstawie rozprawy doktorskiej przedłożonej i obronionej w 1975 r. na Wydziale Biologii i Nauk o Ziemi Uniwersytetu Łódzkiego. Praca ta dotyczyła wewnątrzmiejskich dojazdów do pracy. Promotorem pracy pt. Stopień rozproszenia dojazdów do pracy ludności miasta, na przykładzie Łodzi był ówczesny promotor pracy magisterskiej prof. dr hab. Ludwik Straszewicz. Recenzentami pracy byli - prof. dr hab. Kazimierz Dziewoński (Instytut Geografii i Przestrzennego Zagospodarowania PAN w Warszawie) oraz doc. dr Adam Jelonek (Instytut Geografii Uniwersytetu Jagiellońskiego). Za skróconą wersję rozprawy, opublikowaną w 1979 r. w ramach Studiów Komitetu Przestrzennego Zagospodarowania Kraju PAN 
pt. Rozkłady przestrzenne dojazdów do pracy ludności wielkiego miasta (na przyktadzie Łodzi) został nagrodzony przez Ministra Nauki, Szkolnictwa Wyższego i Techniki (1980 r.). Po uzyskaniu stopnia doktora Nauk Geograficznych Profesor pracował na stanowisku asystenta, z kolei (po zmianach organizacyjnych) - adiunkta w Katedrze Geografii Ekonomicznej, a następnie w Zakładzie Lokalizacji Produkcji i Gospodarki Przestrzennej. Później został adiunktem w Zakładzie Geografii Usług i Studiów Ludnościowych UŁ. W latach 1982-1990 prof. J. Dzieciuchowicz pełnił funkcję kierownika Laboratorium Technik Graficznych i Obliczeniowych w Instytucie Geografii Ekonomicznej i Organizacji Przestrzeni Uniwersytetu Łódzkiego.

Rozprawa habilitacyjna profesora pt. Determinanty demograficzne i spoteczno-ekonomiczne redystrybucji przestrzennej ludności aglomeracji miejskich. Przyklad aglomeracji tódzkiej została obroniona w 1996 r. w Instytucie Geografii i Przestrzennego Zagospodarowania PAN w Warszawie. Funkcję recenzentów w przewodzie habilitacyjnym sprawowali prof. dr hab. Piotr Korcelli (Instytut Geografii i Przestrzennego Zagospodarowania Kraju PAN), prof. dr hab. J. Witkowski (Szkoła Główna Handlowa) oraz prof. dr hab. Robert Rauziński (Uniwersytet Śląski w Opolu). Recenzentem wydawniczym pracy był prof. dr hab. Andrzej Gawryszewski. Od 1997 r. Profesor kierował Zakładem Studiów Ludnościowych i Gospodarki Przestrzennej, a następnie od 2000 r. do 30.09.2013 r. Katedrą Gospodarki Przestrzennej i Planowania Przestrzennego Uniwersytetu Łódzkiego (ryc. 1). Obecnie posiada tytuł naukowy dr hab. i pracuje na stanowisku profesora nadzwyczajnego.

W 2013 r. przeszedł na emeryturę, jednocześnie pracując na część etatu w Katedrze Studiów Ludnościowych i Badań nad Usługami (dawna Katedra Gospodarki Przestrzennej i Planowania Przestrzennego).

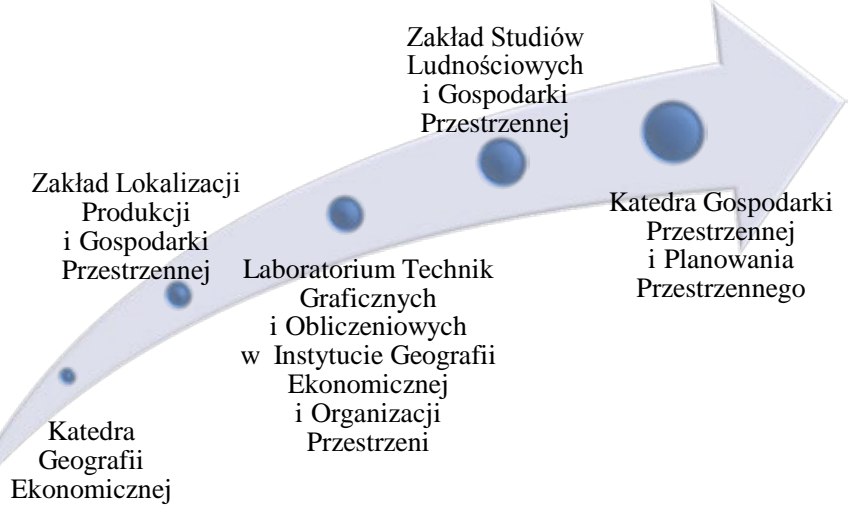

Ryc. 1. Ścieżka zawodowa prof. J. Dzieciuchowicza Źródło: opracowanie własne 
W latach 1976-1977 Profesor przebywał na czteromiesięcznym stażu naukowym w Instytucie Geografii Uniwersytetu Aix-Marseille we Francji. Prowadził tam wykłady $\mathrm{z}$ geografii społeczno-ekonomicznej Polski oraz geografii ludności i osadnictwa. Profesor zgłębiał tam wiedzę dotyczącą najnowszych badań prowadzonych we Francji w zakresie geografii ludności oraz osadnictwa. Zapoznawał się także $\mathrm{z}$ aktualnymi problemami planowania przestrzennego regionu Marsylii, Paryża, Grenoble oraz tzw. Wielkiej Delty. Pobyt w Marsylii miał dla Profesora przełomowe znaczenie, jeżeli chodzi o zainteresowania naukowe. Odbyty staż naukowy oraz nawiązane kontakty naukowe zaowocowały późniejszym opublikowaniem wielu artykułów dotyczących polonii francuskiej oraz współautorstwem Atlasu Polonii Francuskiej. Krótsze misje naukowe odbył w ośrodkach geograficznych w Lyonie (Francja), Lille (Francja), Tbilisi (Gruzja) oraz Portsmouth (Wielka Brytania) - ryc. 2. Rezultatem odbytych przez profesora krótszych i dłuższych wyjazdów oraz stażów naukowych było m.in.: pogłębianie wiedzy, wymiana doświadczeń oraz poznawanie nowoczesnych programów dydaktycznych, a także prezentacja dorobku naukowego.

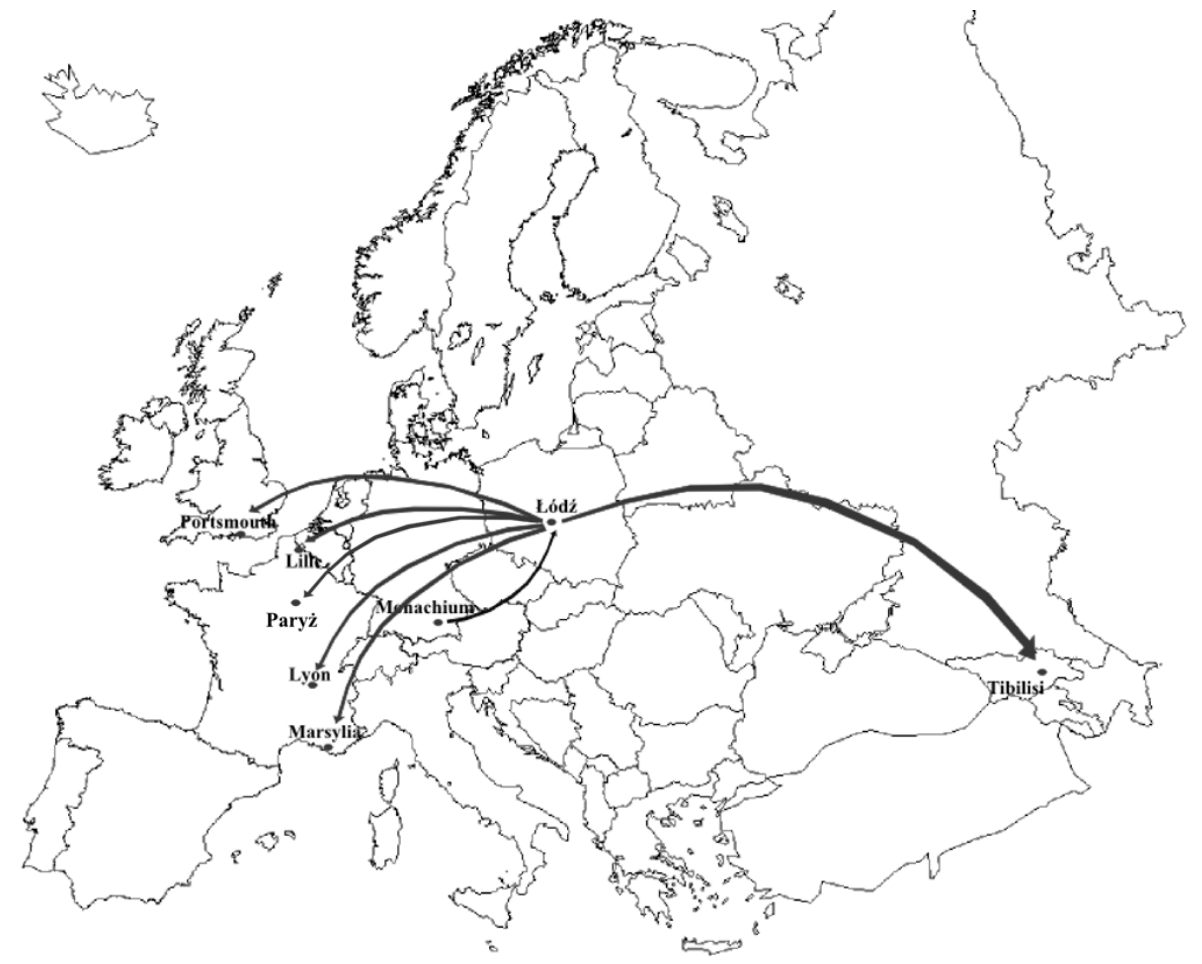

Ryc. 2. Wyjazdy zagraniczne Profesora J. Dzieciuchowicza Źródło: opracowanie własne 
Na uwagę zasługuje także dbałość Profesora J. Dzieciuchowicza o integrację środowiska geografów, zwłaszcza młodych pracowników naukowych. Świadczą o tym zorganizowane przez Profesora konferencje naukowe. J. Dzieciuchowicz był organizatorem lub współorganizatorem wielu międzynarodowych oraz krajowych konferencji, zjazdów oraz seminariów naukowych (1975, 1978, 1990, 1995, 1999, 2000, 2002, 2004, 2007, 2010), pełniąc rolę ich sekretarza naukowego, wiceprzewodniczącego lub przewodniczącego.

Profesor uczestniczył także aktywnie w pracach wydziałowych, uniwersyteckich komisji oraz rad. Uczestniczył m.in. w pracach: Komisji Nagród i Odznaczeń WNG, Komisji Badań i Finansów WNG, Komisji Dydaktycznej WNG, Komisji Wyborczej WBNZ UŁ, Rady Programowej Kierunku Gospodarka Przestrzenna WNG i WZ UŁ, Rady Bibliotecznej UŁ, Rady Bibliotecznej WNG UŁ, senackiej Komisji Dyscyplinarnej dla pracowników naukowo-dydaktycznych UŁ, czy Kolegium Elektorów UŁ. J. Dzieciuchowicz zorganizował współpracę Katedry Gospodarki Przestrzennej i Planowania Przestrzennego UŁ z wieloma instytucjami, biurami oraz jednostkami samorządowymi, towarzystwami i przedsiębiorstwami. Wśród wielu instytucji wymienić można m.in.: Biuro Planowania Przestrzennego Województwa Łódzkiego, Regionalny Ośrodek Badań i Dokumentacji Zabytków w Łodzi, Instytut Europejski, Centralne Muzeum Włókiennictwa, Muzeum Sztuki w Łodzi, Muzeum Kinematografii w Łodzi, Towarzystwo Naukowe Nieruchomości, Kopalnia Węgla Brunatnego „Bełchatów”, czy Elektrownia „Bełchatów”.

Poza działalnością naukowo-badawczą prof. J. Dzieciuchowicz od połowy lat 90. prowadził działalność redakcyjną czasopism naukowych. W latach 19961997 był sekretarzem Redakcji Naukowo-Dydaktycznej Folia Geographica UŁ, następnie w latach 1997-1999 został członkiem Rady Redakcyjnej tego czasopisma. W latach 2000-2012 pełnił funkcję redaktora naczelnego Redakcji Naukowo-Dydaktycznej Folia Geographica Socio-Oeconomica, zaś od 2001 r. jest członkiem Rady Konsultacyjnej Geographia Polonica Wydawnictwa Instytutu Geografii i Zagospodarowania Przestrzennego Polskiej Akademii Nauk. Prof. J. Dzieciuchowicz jest również od 2002 r. redaktorem naczelnym czasopisma wydawanego w Katedrze Gospodarki Przestrzennej i Planowania Przestrzennego UŁ pt. Space-Society-Economy (Przestrzeń-Społeczeństwo-Gospodarka).

W ramach serii wydawniczej monografii naukowych Redakcji Naukowo-Dydaktycznej Folia Geographica Socio-Oeconomica J. Dzieciuchowicz zredagował około 20 prac, natomiast w przypadku czasopisma „Folia Geographica Socio-Oeconomica" był redaktorem naukowym 10 tomów. Oprócz czasopism oraz serii wydawniczych Profesor recenzował wiele prac zbiorowych, w tym habilitacje oraz doktoraty. J. Dzieciuchowicz był członkiem PTG (w latach 
1972-1975 pełnił funkcję sekretarza, a w 1987 r. - prezesa Oddziału Łódzkiego). W latach 1996-1998 był również członkiem zespołu badawczego Komitetu Przestrzennego Zagospodarowania Kraju PAN.

J. Dzieciuchowicz realizował swoje prace badawcze z skali globalnej, regionalnej, a także lokalnej, kładł przy tym nacisk zarówno na płaszczyznę poznawczą, jak i teoretyczno-metodologiczną. Badania prowadzone przez Profesora J. Dzieciuchowicza wchodzą w zakres geografii ludności, geografii społecznej, geografii miast, geografii usług, a także geografii regionalnej, gospodarki przestrzennej i planowania przestrzennego. Zrealizowane przez Profesora prace badawcze obejmują cztery główne nurty badawcze. Pierwszy z nich dotyczy przestrzennych procesów oraz struktur demograficznych i społecznych w miastach, aglomeracjach oraz regionach miejskich, w tym problematyki definitywnych i wahadłowych migracji ludności, a także ewolucji przestrzennej i demograficzno-społecznej emigracji polskiej we Francji. Drugi nurt badawczy dotyczy stanu oraz rozwoju przestrzennego, struktury, waloryzacji oraz typologii przestrzennej budownictwa mieszkaniowego oraz rejonizacji warunków środowiska mieszkaniowego w ośrodkach i regionach miejskich. Natomiast do trzeciego nurtu należą studia nad kierunkami i czynnikami przemian struktury przestrzennej usług. Czwarty nurt reprezentują studia odnoszące się do Łodzi i regionu łódzkiego. Do najważniejszych badawczych osiągnięć teoretycznych J. Dzieciuchowicza należy autorstwo kognitywnej teorii zachowań migracyjnych oraz teorii migracji bazującej na koncepcji kapitału ludzkiego. Wśród wszystkich opracowań publikowanych przez Profesora ogromną rolę odgrywają prace dotyczące Łodzi oraz regionu łódzkiego (ponad 60 publikacji).

J. Dzieciuchowicz był współautorem wielu publikacji, wśród których należy wymienić: Zarys monografii województwa tódzkiego, S. Liszewski (red.) (2001) czy Struktury $i$ procesy ksztattujace tódzki region spoteczno-gospodarczy, A. Jewtuchowicz, A. Suliborski (red.) (2002), Rola wyznań religijnych w ksztattowaniu przestrzeni miejskiej Łodzi, J. Dzieciuchowicz (red.) (2004), Łódź. Monografia miasta wersja polska S. Liszewski (red.) (2006) oraz angielskojęzyczna (2009). Należy także pamiętać o kilku wydaniach Atlasu Miasta Łodzi (wersja polskojęzyczna i angielskojęzyczna). W ciągu kilkudziesięciu lat Profesor zajmował się badawczo budownictwem mieszkaniowym oraz warunkami mieszkaniowymi, czego wynikiem była m.in. monografia pt. Środowisko mieszkaniowe wielkiego miasta. Przyktad Łodzi (2011). Zainteresowania naukowe skupiały się również na usługach, czego przykładem były: redakcja i współautorstwo trzech monografii naukowych pt. Usługi rynkowe $w$ Łodzi w okresie transformacji (2005), Ustugi nierynkowe w przestrzeni miejskiej Łodzi (2006) i Usługi dla producentów i biznesu $w$ przestrzeni wielkomiejskiej. 
Przyktad Łodzi (2009), a także autorstwo publikacji Wielkie centrum handlowe $w$ przestrzeni miejskiej i podmiejskiej. Manufaktura w Lodzi i Ptak w Rzgowie (2012) oraz Handel w przestrzeni wielkomiejskiej. Przykład Łodzi (2013).

W całokształcie działalności naukowo-badawczej J. Dzieciuchowicza ważną dziedzinę stanowiły opracowania aplikacyjne. Profesor był autorem ponad 20 prac aplikacyjnych, prowadzonych $\mathrm{w}$ głównej mierze na potrzeby planowania przestrzennego. Przykładem mogą być m.in.: studia inwentaryzacji urbanistycznej czy projekty badawcze: centralne, międzyresortowe i KBN. Profesor był autorem lub współautorem ekspertyzy dla potrzeb polityki mieszkaniowej na obszarze Bełchatowskiego Okręgu Przemysłowego (1984), ekspertyzy z zakresu polityki regionalnej dotyczącej zachowań migracyjnych ludności byłego województwa łódzkiego (1996), diagnozy potrzeb mieszkaniowych przygotowanych w ramach Studium uwarunkowań i kierunków zagospodarowania przestrzennego Lodzi (1998), prognozy demograficznej Sieradza na lata 19982020 (1998), ekspertyzy funkcjonowania szlaku komunikacyjnego Łódź- Pabianice-Dobroń (2000), czy studium zróżnicowania demograficznego regionu łódzkiego (2001-2002).

Intensywnej oraz owocnej pracy naukowo-badawczej towarzyszyła praca dydaktyczna. Profesor prowadził zajęcia dydaktyczne głównie na kierunku geograficznym Uniwersytetu Łódzkiego m.in. z podstaw geografii społeczno-ekonomicznej, geografii ludności, teorii regionalizacji ekonomicznych oraz metod analizy regionalnej, jak również metod kartografii społeczno-ekonomicznej, metod analiz przestrzennych i wybranych problemów rozwoju aglomeracji łódzkiej. W czasie swojej działalności naukowej profesor J. Dzieciuchowicz wypromował 131 magistrów. Był także promotorem 6 prac doktorskich. Do grona doktorantów wypromowanych przez profesora należą: dr Stanisław Mordwa, dr Lidia Groeger, dr Anna Janiszewska, dr Karolina Dmochowska-Dudek oraz dr Wioletta Kucina i dr Paulina Tobiasz-Lis. W czasie swojej kariery naukowej profesor wydał dotychczas 196 publikacji. Szereg prac ukazało się w renomowanych czasopismach zagranicznych (m.in. L'Espace Geographique) oraz krajowych (m.in. Geographia Polonica czy Przegląd Geograficzny). Największa liczba publikacji dotyczyła procesów, struktur demograficznych oraz społecznych, a także migracji (ok. 60), środowiska mieszkaniowego (ok. 30) oraz usług (ok. 30). Profesor jest także autorem 47 plansz w pięciu atlasach oraz sześciu opisów do plansz.

Rzetelna oraz owocna praca naukowo-badawcza oraz dydaktyczno-wychowawcza Profesora została uhonorowana wieloma nagrodami naukowymi. W1977 uzyskał nagrodę indywidualną Rektora Uniwersytetu Lódzkiego za opublikowanie studium pt. Szczegółowa rejonizacja warunków mieszkaniowych ludności Łodzi w roku 1970. W roku 1980 Profesor został odznaczony nagrodą 
indywidualną Ministra Nauki, Szkolnictwa Wyższego i Techniki za książkę pt. Rozkłady przestrzenne dojazdów do pracy ludności wielkiego miasta (na przykładzie Łodzi). W 1992 r. otrzymał nagrodę indywidualną Rektora UŁ za cykl trzech opublikowanych artykułów, omawiających przestrzenne struktury i procesy demograficzne w aglomeracji łódzkiej. J. Dzieciuchowicz uzyskał cztery nagrody zespołowe za prace pt.: Problemy geografii nasielenija i prostranstwiennoj organizacji (1984), Transformacja spoleczno-ekonomiczna Polski Środkowej (1998), Atlas Polonii Francuskiej (2002) oraz Lódź - monografia miasta (2010). Za współautorstwo w publikacji Atlasu Miasta Łodzi Profesor został uhonorowany nagrodą Ministra Infrastruktury (2004). W roku 2004 Rada Miejska w Łodzi przyznała J. Dzieciuchowiczowi odznakę „Za Zasługi dla Miasta Łodzi". W czasie swojej pracy naukowo-badawczej Profesor został wyróżniony także złotą odznaką Uniwersytetu Łódzkiego (1987), Złotym Krzyżem Zasługi (1988) oraz medalem UŁ w służbie społeczeństwu i nauce (1997) i Medalem Komisji Edukacji Narodowej (2007).

Profesor pozostaje w szczęśliwym związku małżeńskim. Ma dwoje dzieci. Życie rodzinne jest niezwykle cenione i celebrowane przez niego. Poza licznymi zainteresowaniami naukowymi profesor interesuje się także podróżami (choć dziś ich znaczenie jest znacznie mniejsze), literaturą, muzyką, a także filmem. J. Dzieciuchowicz posiada uprawnienia przewodnika górskiego oraz sternika jachtowego.

\section{LITERATURA}

Dzieciuchowicz J., 1995, Biogram naukowy: Jerzy Dzieciuchowicz [w:] Liszewski S. (red.), Geografia osadnictwa i ludności w niepodległej Polsce, lata 1918-1993, t. III, Badacze, PTG, Komisja Geografii Osadnictwa i Ludności, Łódź, s. 26-28.

Dzieciuchowicz J., 1995, Determinanty demograficzne i społeczno-ekonomiczne redystrybucji przestrzennej ludności aglomeracji miejskich (przyktad aglomeracji tódzkiej), Wydawnictwo UŁ, Łódź, $224 \mathrm{~s}$.

Dzieciuchowicz J.Z., 2012, Bibliografia naukowa profesora J. Dzieciuchowicza [rozm. przepr. Kikosicka K., Łódź, 2012, materiały własne].

Strona Katedry Studiów Ludnościowych i Badań nad usługami, http://kgpipp.geo.uni. lodz.pl/index.php [dostęp 10 listopada 2013].

MGR KATARZYNA KIKOSICKA

Uniwersytet Łódzki

Wydział Nauk Geograficznych

Katedra Studiów Ludnościowych i Badań nad Usługami e-mail: kikosicka.k@gmail.com 